\title{
INFLATION PERCEPTIONS AND ANTICIPATIONS IN THE OLD EUROZONE MEMBER STATES
}

\author{
Svatopluk Kapounek, Lubor Lacina*
}

\begin{abstract}
:
There is empirical evidence that the introduction of the euro led to a significant increase of perceived inflation in most countries. Such an increase and persistence in the perceived inflation might then have an impact on inflation expectations and other macroeconomic variables. The authors have used expectational errors to describe the difference between inflation expectations/anticipations and its observed values, subsequently to identify the causality between these variables.
\end{abstract}

Keywords: monetary integration, perceived and anticipated inflation, adaptive and rational expectations hypothesis, stationarity, ADF test, Granger Non-Causality

JEL Classification: E31, F15

\section{Introduction}

The main objective of this paper is to analyze the so-called perceived inflation as observed in the Eurozone countries from the time of euro changeover in 2002. The authors analyzed the empirical paradox presented by the fact that the majority of consumers in Eurozone countries had a feeling that euro introduction caused pronounced overall price growth, when in fact official statistical data measuring the actual course of inflation (e.g., the HICP - Harmonized Index of Consumer Prices) did not bear out these fears to any significant extent.

What risks are actually connected to growth in perceived inflation after introduction of the euro that justify attention to it? Primarily it is the fact that perceived inflation may influence the inflationary expectations of economic actors. In this way, perceived inflation upon introduction of the euro could lead to unpleasant risks associated with accelerated inflation if such subjective feelings were to be reflected in concrete price and wage decisions.

* Svatopluk Kapounek, Lubor Lacina, Mendel University, Faculty of Business Economics, Department of Finance, Zemědělská 1, CZ - 61300 Brno (lacina@mendelu.cz, skapounek@mendelu.cz). The authors benefited from comments by Jarko Fidrmuc, Iika Korhonen, Hubert Gabrisch, Antonín Rusek and participants of the 65th International Atlantic Economic Conference, Warsaw, /Poland/, 9-13 April 2008 and the International Conference Economic and Monetary Union: 10 Years of Success? Brno / Czech Republic/, 27-28 November, 2008. The results introduced in the paper are the outcome of the Research Intent MSM No. 6215648904. The holder is Mendel University of Agriculture and Forestry Brno, Faculty of Business and Economics. The paper is supported by the Czech Science Foundation via grant No. P402/11/0570 with the title "Time-Frequency Approach for the Czech Republic Business Cycle Dating" and by the Jean Monnet Chair Grant No. 2009-2736/001-001 "Dynamics of European Economic and Monetary Integration". 
There is also the question of whether growth in perceived inflation might not impact the trust placed by citizens and other entities in official statistics which follow the course of prices, thereby undermining the rationality of their decision-making processes. ${ }^{1}$ No less important is whether and to what extent feeling-based judgments by the public impact the basic evaluation of costs and benefits associated with introduction of the euro. ${ }^{2}$

A series of studies attempted to address these questions. They may be divided into two main categories: The first group consists of microeconomically-oriented papers focused on a detailed examination of inflation during the transition period leading up to the introduction of the common European currency, broken down by individual consumer expenditure categories (foods, services, etc.). ${ }^{3}$ The second group consists of studies exploring the psychological impact of the introduction of the new currency on people's perceptions, especially their perception of prices. ${ }^{4}$

In this paper, we shall attempt to identify the most important arguments presented in the literature on perceived inflation, simultaneously summarizing what has been learned from studies in both categories. The authors use expectational errors, based on the short-term Phillips curve assumptions, to describe the difference between inflation expectations and its current values.

The paper is structured as follows: Section 1 provides an overview of the theory and empiricism on the gap between measured and perceived inflation. Section 2 then builds up the theoretical framework based on the short-term Phillips curve approach and derives two hypotheses, to be tested subsequently. Section 3 provides the methodology. Section 4 presents the modelling and results of the empirical analysis. In Section 5 authors compare its results and used methodology with papers and studies on a similar topic. Finally, Section 6 concludes and provides recommendations for the economic policy.

\section{Theory and Empiricism on the Gap between Measured and Perceived Inflation}

Gylfason (1980) states the following: "It is interesting to note that while an increase in the expected rate of inflation increases consumption by influencing intertemporal choice, an increase in the price level may at the same time reduce consumption through the Pigou effect. There is inconsistency between the argument that increased

1 If citizens have the "feeling" that prices are growing in spite of the official statistics, perceived inflation may lead to a certain amount of disorientation among members of the public. A similarly disjointed view of price development upon introduction of the euro into circulation was an advanced in Germany, among other countries, where - in spite of the fact that statistics showed the introduction of the euro had no profound impact on inflation - the term "Teuro" came into being, fusing "teuer", which is German for "expensive", with "euro".

2 Growth in perceived inflation is likely one cause of the mixed feelings residents of the eurozone had about the introduction of the common European currency. Surveys like the Flash Eurobarometer (2010) show that the specter of perceived inflation also threatens countries outside the eurozone, where the public was also afraid in advance that the introduction of the euro would lead to higher prices.

3 See ECB (2002a), ECB (2002b), Aucremanne et al. (2007) or Sturm et al. (2009).

4 The most important of these are Brachinger (2006), Jonas et al. (2002) or Traut-Mattausch et al. (2004). 
inflation stimulates consumption at the expense of savings and the fact that in the recession of 1974-1975 high inflation rates and high savings coincided in many industrial countries." ... and continues ... "Even though increased inflation stimulates via increased consumption output and employment in the short run, it may still be detrimental to economic growth as time passes."

The authors of this article assume that exogenous negative shock to an individual wealth ceteris paribus reduces the expected future consumption, therefore increasing the marginal utility of future consumption. To maintain the equilibrium, the marginal utility of the current consumption has to rise - i.e. the current consumption has to be reduced. That is, the share of consumption in GDP declines and the personal savings rate increases. The latter, indeed, will mitigate the negative wealth shock, but it cannot eliminate it. The savings sufficient to increase wealth to its pre-shock levels - and hence to resume the original level of consumption - would violate the individual budget constraint. Because the consumption still remains exogenous of GDP - but not vice versa - the reduction in consumption reduces the GDP's growth.

Significant exogenous negative shock that leads to the expected future consumption reduction is a positive gap between the current and perceived inflation as well. To clarify the term "perceived inflation" we have to look at psychological terminology. In psychology and cognitive sciences perception is defined as "the process of acquiring, interpreting, selecting and organizing sensory information" (Federal Statistical Office of Germany, 2006). The ECB (2007) provides the following interpretation of the link between perceived inflation, inflation expectations and other economic variables: "...protracted divergences in the evolution of measured perceived inflation warrant close examination, given that perceived inflation might have an impact on inflation expectations and other macroeconomic variables."

As will be discussed later, the above-mentioned definition is in line with the methodology of the perceived inflation survey conducted by the European Commission. The indicator of perceived inflation is not constructed with the use of empirical price monitoring. It surveys the feelings of consumers about the past and future price development. Consumer opinions on inflation are collected through the Consumer Survey of the European Commission (Directorate General for Economic and Financial Affairs). As the indicator derived from this survey differs in nature from the HICP, it is not possible to make a direct comparison between the two measures. In order to interpret its dynamics, it is important to gain a better understanding of the methodology used to calculate the European Commission indicator. More details are provided in the methodological part of the paper. Chart 1 shows the development of HICP, perceived and anticipated inflation evaluation in the Eurozone between 1997 and 2009. 
Chart 1

HICP, Inflation Perceptions and Anticipations in the Eurozone (1997-2009)
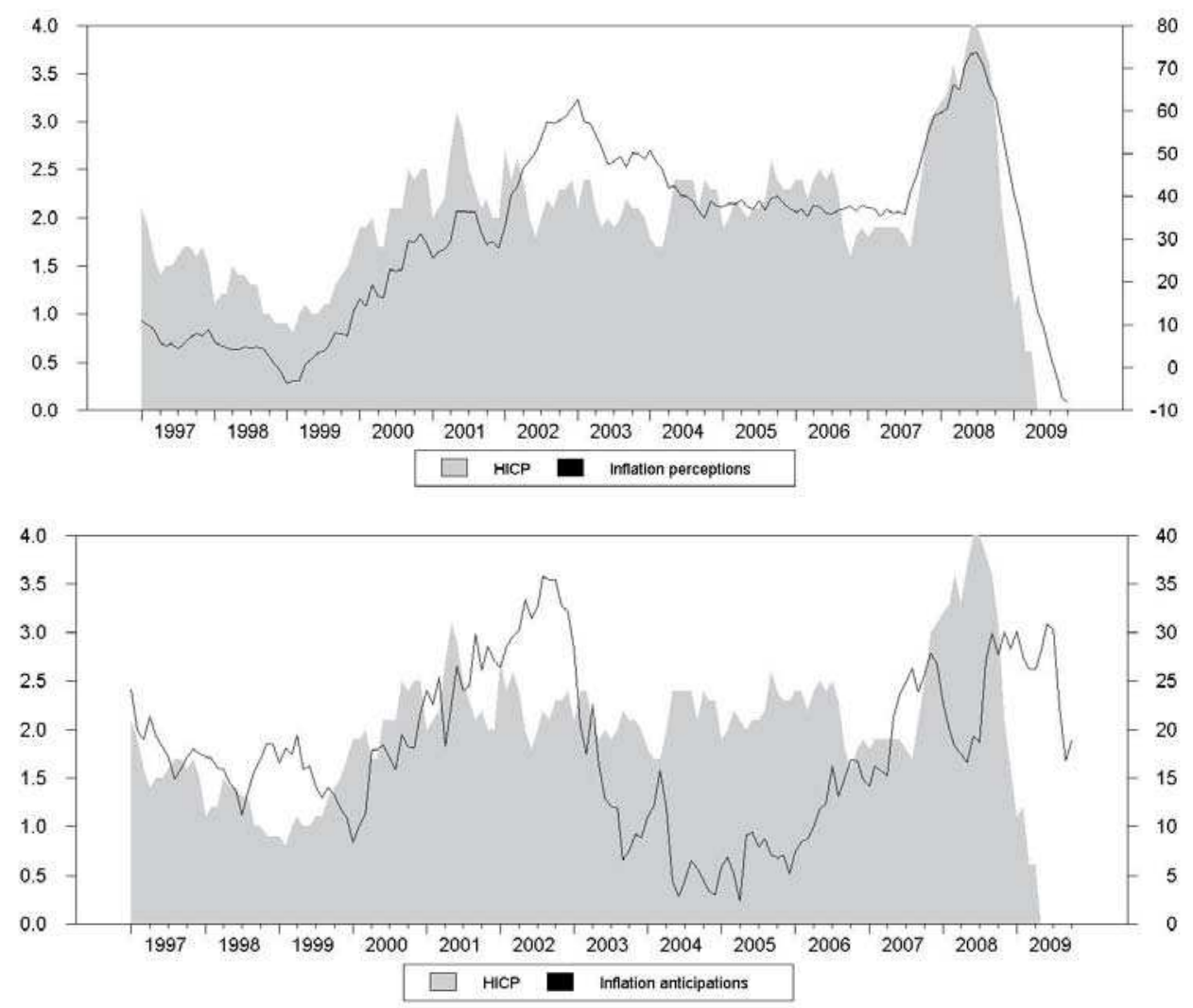

Datasource: Eurostat, European Commission Consumer Survey.

There are many arguments why a gap between measured (HICP) and perceived inflation may have occurred in the aftermath of the euro changeover. The inflation perceptions are mostly based on the price changes of frequently purchased products, different perceptions of price increases and decreases, price shocks and asymmetries in perceptions between the lower priced items and in sectors where price transparency and market concentration are low. For the next part of this paper it is important that "... since 2002 consumers have tended to perceive that inflation is high, while in reality it was relatively low, albeit slightly above the quantified definition of price stability for the euro area." (Aucremann, Collin, Stragier, 2007, p. 24)

Kichler, E. (2006) provides the following argument: "Dealing with the new currency essentially depends on the understanding of the nominal euro values, which can be derived from two different sources". On the one hand, euro amounts can be evaluated on the basis of an interaction of nominal and real representations, which leads to a bias toward nominal valuation (Shafir, Diamond and Tversky, 1997). This bias is influenced, inter alia, by the salience of nominal values as well as simple and 
careful mental calculation processes and is referred to as money illusion (Dimand, 2002). In the context of the influence of the respective former currencies and conversion factors on the perception of euro amounts also the term "euro illusion" was coined (Burgoyne, Routh and Ellis, 1999; Gamble, Gärling, Västfjäll and Marell, 2003). On the other hand, the evaluation of euro amounts can be influenced by specific other values, such as the price one remembers in the former currency or random values. Finally, it is questionable to which periods persons relate estimated inflation rates and to what extent time leads to distorted perceptions. Kemp and Willetts (1996), for example, showed that inflation rates tend to be overestimated by far for the more recent past, while subjective estimates for longer periods lead to a gross underestimation of inflation rates.

Studies of Döhring, B., Mordonu, A. (2007) and Lacina (2008) provide sets of factors that attempted to explain the existence and persistence of a perceived inflation indicator and its deviation from HICP. The following part of the paper describes some of most frequently mentioned factors in both studies.

In most of the euro-area countries the prices of day-to-day purchases of so called "out-of-the-pocket" items (for example food, dinners in restaurants) were growing faster than the prices of less frequent purchases (like cars, refrigerators, etc.). The prices of some products even declined while increasing their utility (for example computers, electronic devices). Due to the fact that consumers are more "sensitive" to changes of day-to-day purchases than to the products with long-term utility, they transfer their feelings about price increases in this group of products to their opinion about overall inflation (the whole consumer basket). At the same time psychological studies show that consumers are more sensitive to the price increases in comparison to price decreases. While evaluating the development of prices in the past the surveyed consumers were giving significantly higher weight to the products with price increases compared with those with price decreases.

According to public opinion surveys (Eurobarometers) even 6 years after the euro introduction (cash form) there was still a high percentage of respondents that convert the euro prices to the former national currency. But doing so, they are comparing current prices with prices that existed 6 years prior (at the end of the year 2001).

An important role is also played by expectations. While the consumers (due to media information, conversations with neighbours, declarations of europessimistic politicians, etc.) acquire the strong believe that the introduction of the euro will lead to price increases, they have a tendency to increase their opinion about future development of inflation by their expectations and acquired information in the past. Once expectations about the development of prices after the euro's introduction are set, they have the tendency to be transformed to the long-term increase in perceived inflation compared to the inflation measured by standard price indices like HICP.

Any household is an "ideal" consumer according to the weighted structure of the consumer basket. Logically the higher is the weight in consumption given to the groups of products with higher increases of prices than average (during the euro changeover - like food products), and the higher is then an increase in the indicator of perception inflation.

One of the most mentioned causes of a significant opening of scissors between perceived inflation and inflation measured by HICP is the unawareness of consumers about the structure of the consumer basket and calculation of the consumer price index.

An important fact why the consumer may feel that prices went significantly up 
after the euro introduction is the statistically observed increase of houses prices after the year 2001 (which has nothing to do with the euro introduction). However, therefore the prices of houses are not included in the calculation of HICP, the people that do not know the structure of the consumer basket that is used for HICP calculation, may feel the cost of living is growing. They can then wrongly transform their feelings about the decrease in their purchasing power to the fact that prices went up.

The feeling that "costs of living are increasing" may be influenced not just by increases of prices included (or excluded - real estate) in HICP, but also by the slower growth of wages compared with past developments before euro introduction (due to the attempt of the national government to control inflation growth during the euro changeover, as in Slovenia) or other factors that do not have any direct relation to the euro introduction. Again the people have a tendency to transform their feeling about the decline of purchasing power of their incomes due to the slowdown in nominal wage growth to the introduction of the euro.

An important role in the formation, growth and long-term persistence of perceived inflation are played by information provided by mass media. In countries implementing the euro in the past there was, according to media monitoring, a significant increase in the number of papers covering the topic of inflation. As far as the media have a tendency to choose more "sensational" information (in contrast with rational arguments) in the context of euro changeover, they preferred to be alert mainly to price increases. The media also increased the number of papers analyzing the problem of the official price statistics' credibility (as perceived inflation significantly deviated from HICP before and after euro introduction) and thus creating the opinion that official statistics (like HICP) are providing wrong information about price development for the decisions of consumers.

The following table describes the development of HICP and the perceived inflation indicator in individual Eurozone member countries after euro adoption.

Table 1

Evolution of HICP and Perceived Inflation Indicator in Selected Eurozone Member Countries after Euro Adoption

\begin{tabular}{|c|c|c|c|c|c|c|}
\hline & Avera & $\begin{array}{l}\text { HICP inflation } \\
\text { nual percent }\end{array}$ & hanges & $\begin{array}{r}\text { Per } \\
\text { Percenta }\end{array}$ & $\begin{array}{l}\text { lons of price } \\
\text { lances, seaso }\end{array}$ & $\begin{array}{l}\text { adjusted } \\
\text { adjo }\end{array}$ \\
\hline & $1999-2001$ & $2002-2004$ & $2005-2006$ & $1999-2001$ & $2002-2004$ & $2005-2006$ \\
\hline Belgium & 2,1 & 1,6 & 2,4 & 29 & 44 & 53 \\
\hline Germany & 1,3 & 1,4 & 1,9 & 23 & 48 & 27 \\
\hline Ireland & 3,9 & 3,7 & 2,4 & 40 & 53 & 38 \\
\hline Greece & 2,9 & 3,5 & 3,4 & 18 & 57 & 66 \\
\hline Spain & 2,8 & 3,2 & 3,5 & 20 & 52 & 52 \\
\hline France & 1,4 & 2,1 & 3,2 & 5 & 45 & 47 \\
\hline Italy & 2,2 & 2,6 & 2,1 & 25 & 52 & 37 \\
\hline Luxembourg & 2,4 & 2,6 & 2,6 & - & 38 & 41 \\
\hline Netherlands & 3,2 & 2,5 & 2,5 & 28 & 61 & 25 \\
\hline Austria & 1,6 & 1,6 & 1,6 & -1 & 36 & 35 \\
\hline Portugal & 3,1 & 3,1 & 3,1 & 29 & 46 & 42 \\
\hline Finland & 2,3 & 1,2 & 1,2 & -11 & -5 & -4 \\
\hline
\end{tabular}

Datasource: Eurostat and European Commission Consumer Survey.

Note: Data on inflation perceptions for Luxembourg are only available from January 2002 onwards. 
As we can see there was no significant increase in HICP in any observed country. The opposite is true for the indicator of perceived inflation. In all countries except Finland there was a significant increase in the perceived inflation indicator. What is interesting is that in some countries after the dramatic increase of indicator after euro introduction in cash form (period 2002-2004), the value of the indicator started decreasing. In some countries the indicator remained fixed at a high level. In no country did the indicator of a perceived inflation come back to its former level until the end of 2006.

The significance of the gap between the current and perceived inflation is discussed in the next parts of the paper.

\section{Theoretical Framework of the Paper}

The theoretical background of the relationship between the inflation perceptions and current inflation is possible to find in the short-term Phillips curve. This relationship describes differences between the inflation expectations and its current values, subsequently identifies impact of this differences on the other economic indicators. The common theoretical argument explaining the differences is based on the slow adjustment of prices in the short-term. This limit in the adjustment mechanism is used by monetary and fiscal policy makers in the process of inflation and unemployment determination in the real economy in the short-term. Friedman (1968) gives a theoretical framework for the Phillips curve, in which he introduces the adaptive expectations. The adaptive expectation hypothesis states that price level is given in the short-run, but moves slowly to correct for past expectational errors:

$$
P_{t+1}^{e}=P_{t}+(1-\lambda)\left[P_{t}^{e}-P_{t}\right] \quad 0<\lambda<1
$$

"This equation says that households expect the price in the future period $t+1$ to be equal to the actual price in the current period t if their expectations proved correct in the current period. If, instead, they have mis-estimated the price level in the current period $\left(P_{t}^{e} \neq P_{t}\right)$, they incorporate part of the expectational error in the revision of their expectation in the current period, where $\lambda$ represents the speed with which households update their price expectations." (Heijdra, Ploeg, 2002, p. 8) Assume the substitution of the expectational errors from the formula (1) with the perception errors that represent the gap between perceived and current inflation.

Under the adaptive expectation hypothesis and neo-Keynesian assumptions, expansion of the nominal money supply lowers the interest rate and pushes up aggregate demand in the short-run. With the aggregate demand and national income increasing, the price level rises too. Over time the expected price level is revised upwards and aggregate supply shifts back until the equilibrium of employment and output are reached again. The final recommendation for the policy-makers leads to an assumption of neutrality money in the long-run but not in the short-run. Concurrently, Milton Friedman and other monetarists assumed that there is a temporary effect of nominal money supply expansion on the real output under the adaptive expectation hypothesis.

The problem of expectations was further discussed by Muth (1961). He argues that "expectations, since they are informed predictions of future events, are essentially 
the same as the predictions of the relevant economic theory." (Muth, 1961, p. 316) According to this assumption, the agents can calculate a future correct price level for the new money supply after the monetary policy expansion is implied. The expectational error $\left(P_{t}^{e}-P\right)$ from the form (1) disappeared. The rational expectations hypothesis defines an expectational equilibrium as follows:

$$
P_{t+1}^{e}=P_{t+1} .
$$

From the supply side view, the suppliers must decide on the production capacity before knowing exactly what will be the price at which they can sell their goods. The agents make their decisions on the basis of all information that is available to them. They know prices in the period $t-1$ and $t$. According to the rational expectations hypothesis, there is no significant and permanent gap between the future, past and current inflation rates and its perceptions. However, there is not direct substitution between the rational and adaptive expectation hypothesis. Formula (1) which represents adaptive expectational error could be rewritten in the form:

$$
P_{t}^{e}=P_{t-1}+(1-\lambda)\left[P_{t-1}^{e}-P_{t-1}\right] \quad 0<\lambda<1 .
$$

Obviously, while the rational expectation hypothesis is forward-looking, the adaptive expectation hypothesis is backward-looking. Assume that expectations play a crucial role in economic reality. If the current price level is different from perceived prices:

$$
P_{t}^{P} \neq P_{t}
$$

there is a significant causality between the physical magnitudes of inflation and its perceived intensity. This idea is based on the Weber-Fechner law (Gerrit, 2008). Although the differences between the inflation and its perceptions disappear in the long run, the short-term Phillips curve is impacted. In this paper, the empirical analysis focuses on the inflation perceptions and its relationship with the rational and adaptive expectation hypothesis.

The expectations-augmented Phillips curve indicates that when expectations of future inflation (the future price level) are totally accurate, so that current unemployment equals to its natural level:

$$
\pi_{i t}-\pi_{i t}^{e}=-d\left(U_{i t}-U_{i t}^{n}\right)+v_{i t}
$$

where $\pi_{i t}^{e}$ represents inflation expectations, $\pi_{i t}$ current inflation, $U_{i t}^{n}$ is the natural rate of unemployment, ${ }^{5} U_{i t}$ its current level and $v_{i t}$ unexpected exogenous supply shocks. On the opposite site of the original version of the Phillips curve (Phillips, 1958) where only one Phillips curve exists, the expectation-augmented Phillips curve supposes an infinite number of the curves for each expected inflation rate.

In the empirical analysis, the authors test the hypothesis to see if there is a significant expectational error between the current inflation and its perceptions $\left(P_{t}^{P} \neq P_{t}\right)$ or/and anticipations $\left(P_{t+1}^{P} \neq P_{t+1}\right)$.

5 In the empirical analysis to estimate the natural level of unemployment the Hodrick-Prescott filter is used. 


\section{Technical Background}

The perceived inflation indicator is based on inflation perceptions in the consumer survey of the standardized balance statistic conducted by the European Commission. This statistic is the result of the question: "How do you think that consumer prices have developed over the last 12 months?" There are six possible answers to the question on inflation perceptions: A(1), "risen a lot", A(2), "risen moderately", A(3), "risen slightly", A(4), "stayed about the same", A(5), "fallen" and A(6), "do not know". The balance statistic is computed as follows:

$$
B_{i t}=A_{i t}(1)+0,5 A_{i t}(2)-0,5 A_{i t}(4)-A_{i t}(5) .
$$

where $i$ represents country and $t$ time. The statistic $\mathrm{B}_{\mathrm{it}}$ is in the scale range from -100 to 100 . For the empirical analysis a quantified measure of perceived inflation is needed. The transformation of balance statistic data is based on the harmonized index of consumer prices and $\mathrm{B}_{\mathrm{it}}$ statistic standardization:

$$
\frac{\pi_{i t}^{P}-\bar{\pi}_{i}}{s_{\rho_{i}}}=\frac{B_{i t}-\bar{B}_{i}}{s_{B_{i}}}
$$

where $\pi_{i t}^{P}$ represents a quantified measure of perceived inflation, $\bar{\pi}_{i}$ mean of current inflation (harmonized index of consumer prices) and $s_{\rho i}$ its standard deviation. Correspondently statistic $B_{i t}, \bar{B}_{i}$ and $s_{B_{i}}$. The equation (7) is reversed in the following form (Aucremanne, Collin, Stragier, 2007):

$$
\pi_{i t}^{P}=\frac{\left(B_{i t}-\bar{B}_{i}\right)}{s_{B_{i}}} s_{\rho_{i}}+\bar{\pi}_{i}
$$

Inflation anticipation is based on the consumer survey of the standardized balance statistic, which is the result of the question on the prices development over the next 12 months. Anticipated inflation is quantified by the same way (8) as the perceived inflation.

In the second part of the empirical analysis there will be test of whether there are significant expectational errors $\left(P_{t}^{P} \neq P_{t}\right)$ and $\left(P_{t+1}^{P} \neq P_{t+1}\right)$, represented by the inflation gap $\left(\mathrm{GAP}_{\mathrm{it}}\right)$ :

$$
G A P_{i t}=\pi_{i t}^{P}-\pi_{i t}
$$

The authors verify explicitly whether perceived or/and anticipated inflation track measured inflation by the rejection of the null hypothesis of a unit root over the test period (Aucremanne, Collin, Stragier, 2007). If the current price level is permanently different from perceived prices, the $\mathrm{GAP}_{\text {it }}$ sequence is not stationary (Enders, 2003, pp.185-195). To test the stationarity (unit root) the empirical analysis uses the Augmented Dickey-Fuller test.

GAP between the current and perceived/anticipated inflation could contains various noises, ${ }^{6}$ therefore level stationarity is tested. "The Augmented Dickey-Fuller

6 Permanent noises in the gap between the perceived/anticipated inflation and HICP price level could be caused by measurement errors in inflation perceptions or perceived/anticipated inflation quantification methodology. 
test is used in the form:

$$
\Delta G A P_{i, t}=\alpha_{i}+\delta_{i} G A P_{i, t-1}+\sum_{j=1}^{p_{i}-1} \delta_{i, j} \Delta G A P_{i, t-j}+\varepsilon_{i, t}
$$

where $\rho_{i}$ is the sum of the autoregressive coefficients in an AR-model or order $p_{i}$, and $\varepsilon_{i t}$ is white noise. The optimal lag length of the AR-model is obtained on the basis of Akaike's and Schwarz's Bayesian information criterion under the null hypothesis, $G A P_{i t}$ is assumed to have a unit root." (Aucremanne, Collin, Stragier, 2007)

Subsequently, the parameters $\alpha$ (referring to the constant or drift) and $\delta$ (linear time trend) are jointly tested to contribute for the robustness of the empirical analysis results. The F-test is given by

$$
F=\frac{\left(S S R_{r}-S S R_{u}\right) / r}{S S R_{u} /(n-k)}
$$

where $\mathrm{SSR}_{\mathrm{r}}$ represents sum of squared residuals from the restricted equation, $\mathrm{SSR}_{\mathrm{u}} \mathrm{Sum}$ of squared residuals from the unrestricted equation, n number of usable observations, $\mathrm{k}$ number of the coefficients in the unrestricted equation and $\mathrm{r}$ represents number of restrictions. (Seddighi, Lawler, Katos, 2000, pp. 262-272). The joint hypothesis used in the analysis is the following:

$$
\begin{gathered}
H_{0}: \alpha_{i}=\delta_{i}=0, \text { if } F>\Phi_{1} \\
H_{a}: \text { not both } \alpha_{\mathrm{i}} \text { and } \delta_{\mathrm{i}}=0 \text {, if } F>\Phi_{1}
\end{gathered}
$$

Rejection of the unit roots hypothesis indicates stationarity, the fact that there are not significant expectational errors between the anticipated/perceived and currently observed inflation. Consequently, the current observed inflation is adjusted by its anticipations and/or perceptions.

Another important question of the empirical analysis lies in the assumption of causality between the inflation anticipations and perceptions. If there are significant expectational errors, aggregate prices are not able to be affected by inflation perceptions and/or participation. In that case, current observed inflation is exogenous variable in the relation with the perceived and/or anticipated inflation. To identify independency between the two variables focus now on the exogeneity definition. Assume that the regression relationship is linear:

$$
y_{t}=\beta_{1}+\beta_{2} x_{t}+\varepsilon_{t}
$$

and transform the model (1) into the next equation:

$$
y_{t}=E\left[y_{t} \mid x_{t}\right]+\left(y-E\left[y_{t} \mid x_{t}\right]\right)
$$

where the condition $E\left[y_{t} \mid \varepsilon_{t}\right]=0$. Analogically there could be defined variable $x_{t}$. To identify the independency between the variables must be defined exogenous variable in the equation (14):

$$
f\left(y_{t}, x_{t}\right)=f\left(y_{t} \mid \beta, x_{t}\right) \times f\left(\theta, x_{t}\right),
$$


"where the parameters in the conditional distribution do not appear in and are functionally unrelated to those in the marginal distribution of $x_{t}$. By this arrangement, we can think of "autonomous variation" of the parameters of interest, $\beta$. The parameters in the conditional model for $y_{t} \mid x_{t}$ can be analyzed as if they could vary independently of those in the marginal distribution of $x_{t}$. If this condition does not hold, then we cannot think of variation of those parameters without linking that variation to some effect in the marginal distribution of $x_{t}$. In this case, it makes little sense to think of $x_{t}$ as somehow being determined "outside" the model." (Green, 2003, p. 591).

To reject or accept the hypothesis about the independency was used Granger non-causality approach, known also as strong exogeneity. Assume this equation:

$$
E\left[y_{t} \mid y_{t-1}, x_{t-1}, x_{t-2}, \ldots\right]=E\left[y_{t} \mid y_{t-1}\right]
$$

which could be interpreted, if once we condition on past values of the dependent variable $y_{t}$, lags of the independent variable $x_{t}$ do not explain any variation in the current value of the dependent variable $y_{t}$. In practice, the sequence of lags of variable $x$ has to be truncated, and additional lags of $y$ are included in the model. In Grange non-causality approach will be used model:

$$
y_{t}=\alpha+\beta_{1} y_{t-1}+\beta_{2} y_{t-2}+\gamma_{1} x_{t-1}+\gamma_{2} x_{t-2}+\varepsilon_{t}
$$

If the empirical analysis fails to reject the hypothesis $\gamma_{1}=\gamma_{2}=0$ and simultaneously reject the hypothesis $\beta_{1}=\beta_{2}=0$, the variable $y$ is exogenous. In this case will be rejected the hypothesis about the causality existence between the variables in Granger sense.

\section{Data and Empirical Analysis Results}

Tests are applied on monthly data of the harmonized index of consumer prices and consumer surveys in the Eurozone and its 12 Member States for the estimation period 1997:01-2008:12. The unit-root tests are reported in Tables 2, 3, 4 and 5. The ADF test applied in Tables 2 and 4 use Akaike's information criterion to identify lag order, Tables 3 and 5 Schwarz's Bayesian information criterion. Both of these information criteria determine the appropriate number of lagged differences by adding lags until the Ljung-Box test fails to reject any serial correlation at a defined level. The difference between these approaches is that Schwarz's Bayesian information criterion gives a more parsimonious lag structure.

From the Augmented Dickey-Fuller unit root test point of view, for Italy and Luxembourg, the unit root can be rejected at a $1 \%$ significance level. On a $5 \%$ significance level this hypothesis is rejected for Belgium and a 10\% significance level for the Netherlands and Ireland. Similar results are presented by the joint test. For Italy in the sample, the null of the unit root and no constant is accepted at $1 \%$, for Belgium and Luxembourg at $5 \%$ and for the Netherlands at a $10 \%$ significance level. 
Table 2

Augmented Dickey-Fuller Unit Root Test for Perceived Inflation Gap (GAP $\left.{ }_{\text {it }}{ }^{p}\right)$

\begin{tabular}{|lcccc|}
\hline Country & Lag Order $\left(\mathrm{p}_{\mathrm{i}}\right)^{\mathrm{b}}$ & t statistic & $\Phi_{1}$ statistic $^{\mathrm{c}}$ & observations $^{\text {E }}$ \\
\hline EA 12 & 12 & $-2,1053$ & 2,2380 & 120 \\
Austria & 16 & $-2,1225$ & 2,3315 & 144 \\
Belgium & 1 & $-3,1637 * *$ & $5,0553 * *$ & 144 \\
Finland & 1 & $-1,9858$ & 2,0672 & 144 \\
France & 12 & $-2,5182$ & 3,2920 & 144 \\
Germany & 1 & $-2,1428$ & 2,4693 & 144 \\
Greece & 9 & $-1,5065$ & 1,5397 & 144 \\
Ireland & 0 & $-2,7502 *$ & 3,8048 & 136 \\
Italy & 0 & $-4,2381 * * *$ & $9,0842 * * *$ & 144 \\
Luxembourg & 0 & $-3,5365 * * *$ & $6,4103 * *$ & 84 \\
Netherlands & 8 & $-2,7778 *$ & $3,8633 *$ & 144 \\
Portugal & 0 & $-2,4134$ & 2,9955 & 144 \\
Spain & 19 & $-1,3502$ & 1,0319 & 144 \\
\hline
\end{tabular}

Notes: a Critical values at $1 \%, 5 \%$, and $10 \%$ are $-3,46,-2,88$, and $-2,57$.

b Lag order is chosen using Akaike's information criterion.

c Joint test of a unit root and no constant. Critical values at $1 \%, 5 \%$, and $10 \%$ are $6,52,4,63$, and 3,81 .

The level stationarity of inflation gap between the perceived and current inflation is expected only in Belgium, the Netherlands, Italy and Luxembourg. In other Eurozone Member Countries expectational error are significantly assumed in the analyzed period.

Table 3

Augmented Dickey-Fuller Unit Root Test for Perceived Inflation Gap ( $\mathrm{GAP}_{\mathrm{it}}{ }^{\mathrm{p}}$ )

\begin{tabular}{|lcccc|}
\hline Country & Lag Order $\left(\mathrm{p}_{\mathrm{i}}\right)^{\mathrm{b}}$ & t statistic & $\Phi_{1}$ statistic $^{\mathrm{c}}$ & observations \\
\hline EA 12 & 0 & $-3,3884^{* * *}$ & $5,8390^{* *}$ & 120 \\
Austria & 0 & $-3,0796^{* * *}$ & $4,8529 * *$ & 144 \\
Belgium & 0 & $-3,7773^{* * *}$ & $7,1677 * * *$ & 144 \\
Finland & 0 & $-2,4893$ & 3,2115 & 144 \\
France & 0 & $-3,4485^{* *}$ & $6,0973 * *$ & 144 \\
Germany & 0 & $-2,5863^{*}$ & 3,4987 & 144 \\
Greece & 0 & $-2,4387$ & $3,8224 *$ & 144 \\
Ireland & 0 & $-2,7502^{* *}$ & 3,8048 & 136 \\
Italy & 0 & $-4,2381 * * *$ & $9,0842 * * *$ & 144 \\
Luxembourg & 0 & $-3,5365 * * *$ & $6,4103 * *$ & 84 \\
Netherlands & 0 & $-1,8180$ & 1,6529 & 144 \\
Portugal & 0 & $-2,4134$ & 2,9955 & 144 \\
Spain & 1 & $-3,1383 * *$ & $5,0916^{* *}$ & 144 \\
\hline
\end{tabular}

Notes: $\quad$ a Critical values at $1 \%, 5 \%$, and $10 \%$ are $-3,46,-2,88$, and $-2,57$.

' Lag order is chosen using Schwarz's Bayesian information criterion.

c Joint test of a unit root and no constant. Critical values at $1 \%, 5 \%$, and $10 \%$ are $6,52,4,63$, and 3,81 .

Table 3 presents the ADF stationarity test, where lag order was chosen using the Schwarz's Bayesian criterion. In comparison with Table 2, these results are more 
realistic due to the identified lag order. Short-term period specified in the theoretical background corresponds only to a few months. In the Table 3 , the unit root can be rejected at a $1 \%$ significance level for EA12, Austria, Belgium, Italy and Luxembourg. At a 5\% significance level for France, Ireland and Spain, for Germany at a 10\% significance level. The expectational error $\left(P_{t}^{e} \neq P_{t}\right)$ is not rejected at a $10 \%$ significance level only in Finland, Greece, the Netherlands and Portugal. We can conclude that expectational errors are not significant in the Eurozone Member States (Table 2 and 3).

Table 4

Augmented Dickey-Fuller Unit Root Test for Anticipated Inflation Gap (GAP ${ }_{\mathrm{it}}{ }^{\text {a }}$ )

\begin{tabular}{|lcccc|}
\hline Country & Lag Order $\left(\mathrm{p}_{\mathrm{i}}\right)^{\mathrm{b}}$ & t statistic & $\Phi_{1}$ statistic $^{\mathrm{c}}$ & observations $^{\text {EA 12 }}$ \\
Austria & 12 & $-1,9247$ & 1,9458 & 132 \\
Belgium & 11 & $-5,4371 * * *$ & $14,8987 * * *$ & 144 \\
Finland & 0 & $-3,6237 * * *$ & $6,5799 * * *$ & 144 \\
France & 11 & $-3,409 * *$ & $4,9819^{* *}$ & 144 \\
Germany & 0 & $-4,1789 * * *$ & $8,7447 * * *$ & 144 \\
Greece & 0 & $-2,3714$ & 2,8128 & 144 \\
Ireland & 0 & $-3,3728^{* *}$ & $5,8324 * *$ & 144 \\
Italy & 0 & $-3,4029 * *$ & $5,8646 * *$ & 144 \\
Luxembourg & 0 & $-2,6691 *$ & 3,562 & 144 \\
Netherlands & 0 & $-2,3332$ & 2,8515 & 72 \\
Portugal & 0 & $-2,2399$ & 2,5337 & 144 \\
Spain & 1 & $-2,9727 * *$ & $4,5561 *$ & 144 \\
\hline
\end{tabular}

Notes: ${ }^{a}$ Critical values at $1 \%, 5 \%$, and $10 \%$ are $-3,46,-2,88$, and $-2,57$.

${ }^{b}$ Lag order is chosen using Akaike's information criterion.

c Joint test of a unit root and no constant. Critical values at $1 \%, 5 \%$, and $10 \%$ are $6,52,4,63$, and 3,81 .

Table 5

Augmented Dickey-Fuller Unit Root Test for Anticipated Inflation Gap $\left(\mathrm{GAP}_{\mathrm{it}}{ }^{\mathrm{a}}\right)$

\begin{tabular}{|lcccc|}
\hline Country & Lag Order $\left(\mathrm{p}_{\mathrm{i}}\right)^{\mathrm{b}}$ & t statistic & $\Phi_{1}$ statistic $^{c}$ & observations \\
\hline EA 12 & 0 & $-2,5025$ & 3,1637 & 132 \\
Austria & 0 & $-3,6167^{* * *}$ & $6,7334^{* * *}$ & 144 \\
Belgium & 0 & $-3,6237^{* * *}$ & $6,5799 * * *$ & 144 \\
Finland & 0 & $-3,0047^{* *}$ & $4,5944 *$ & 144 \\
France & 0 & $-4,1789 * * *$ & $8,7447 * * *$ & 144 \\
Germany & 0 & $-2,3714$ & 2,8128 & 144 \\
Greece & 0 & $-3,3728^{* * *}$ & $5,8324 * *$ & 144 \\
Ireland & 0 & $-3,4029 * *$ & $5,8646 * *$ & 144 \\
Italy & 0 & $-2,6691 *$ & 3,562 & 144 \\
Luxembourg & 0 & $-2,3332$ & 2,8515 & 72 \\
Netherlands & 0 & $-2,2399$ & 2,5337 & 144 \\
Portugal & 0 & $-2,9072 * *$ & $4,4572 *$ & 144 \\
Spain & 0 & $-2,5447$ & 3,3622 & 144 \\
\hline
\end{tabular}

Notes: ${ }^{a}$ Critical values at $1 \%, 5 \%$, and $10 \%$ are $-3,46,-2,88$, and $-2,57$.

b Lag order is chosen using Schwarz's Bayesian information criterion.

c Joint test of a unit root and no constant. Critical values at $1 \%, 5 \%$, and $10 \%$ are $6,52,4,63$, and 3,81 . 
The stationarity test in the level for the gap between the anticipated and current inflation is present in Tables 3 and 4. The different results are caused by different criterion to choose lag. The authors prefer Schwarz's Bayesian information criterion, due to the shorter lags in the Table 5.

Table 6

Granger Non-Causality Test of Perceived Inflation

\begin{tabular}{|c|c|c|c|c|c|c|}
\hline Country & $\alpha$ & $\beta_{1}$ & $\beta_{2}$ & $\gamma_{1}$ & $V_{2}$ & F-statistics \\
\hline EA 12 & $\begin{array}{c}0,1319 \\
(0,0815)\end{array}$ & $\begin{array}{c}0,9763 \\
(0,0990)^{* * *}\end{array}$ & $\begin{array}{c}-0,1497 \\
(0,0973)\end{array}$ & $\begin{array}{c}-0,1785 \\
(0,3172)\end{array}$ & $\begin{array}{c}0,2840 \\
(0,3071)\end{array}$ & $\begin{array}{c}146,2016 \\
(0,2028)^{* * *}\end{array}$ \\
\hline Austria & $\begin{array}{c}0,0968 \\
(0,0648)\end{array}$ & $\begin{array}{c}0,7868 \\
(0,0931)^{* * *}\end{array}$ & $\begin{array}{c}0,0869 \\
(0,0930)\end{array}$ & $\begin{array}{c}0,3557 \\
(0,2234)\end{array}$ & $\begin{array}{c}-0,2862 \\
(0,2197)\end{array}$ & $\begin{array}{c}213,7227 \\
(0,3020)^{* * *}\end{array}$ \\
\hline Belgium & $\begin{array}{c}0,1188 \\
(0,0904)\end{array}$ & $\begin{array}{c}0,8269 \\
(0,0854)^{* * *}\end{array}$ & $\begin{array}{l}-0,0198 \\
(0,0851)\end{array}$ & $\begin{array}{l}-0,0974 \\
(0,1687)\end{array}$ & $\begin{array}{c}0,2371 \\
(0,1697)\end{array}$ & $\begin{array}{c}160,6868 \\
(0,4589)^{* * *}\end{array}$ \\
\hline Finland & $\begin{array}{c}0,0878 \\
(0,0607)\end{array}$ & $\begin{array}{c}0,8965 \\
(0,0953)^{* * *}\end{array}$ & $\begin{array}{c}0,0540 \\
(0,0951)\end{array}$ & $\begin{array}{c}-0,0202 \\
(0,1209)\end{array}$ & $\begin{array}{c}0,0309 \\
(0,1195)\end{array}$ & $\begin{array}{c}303,0967 \\
(0,3414)^{* * *}\end{array}$ \\
\hline France & $\begin{array}{c}0,1131 \\
(0,0638) *\end{array}$ & $\begin{array}{c}1,0222 \\
(0,0891)^{* * *}\end{array}$ & $\begin{array}{c}-0,2508 \\
(0,0889)^{* * *}\end{array}$ & $\begin{array}{c}0,3674 \\
(0,2480)\end{array}$ & $\begin{array}{l}-0,2057 \\
(0,2445)\end{array}$ & $\begin{array}{c}219,2791 \\
(0,2918)^{* * *}\end{array}$ \\
\hline Germany & $\begin{array}{c}0,1631 \\
(0,0732)^{* *}\end{array}$ & $\begin{array}{c}0,8310 \\
(0,0927)^{* * *}\end{array}$ & $\begin{array}{c}0,0654 \\
(0,0914)\end{array}$ & $\begin{array}{c}0,3148 \\
(0,2135)\end{array}$ & $\begin{array}{c}-0,3191 \\
(0,2101)\end{array}$ & $\begin{array}{c}151,4084 \\
(0,3224)^{* * *}\end{array}$ \\
\hline Greece & $\begin{array}{c}0,3852 \\
(0,1687)^{* *}\end{array}$ & $\begin{array}{c}0,8970 \\
(0,910)^{* * *}\end{array}$ & $\begin{array}{l}-0,0116 \\
(0,0874)\end{array}$ & $\begin{array}{c}-0,1112 \\
(0,1815)\end{array}$ & $\begin{array}{c}0,1101 \\
(0,1818)\end{array}$ & $\begin{array}{c}160,2620 \\
(0,3853)^{* * *}\end{array}$ \\
\hline Ireland & $\begin{array}{c}0,2005 \\
(0,0911)^{* *}\end{array}$ & $\begin{array}{c}1,0255 \\
(0,0884)^{* * *}\end{array}$ & $\begin{array}{l}-0,0620 \\
(0,0924)\end{array}$ & $\begin{array}{c}0,0740 \\
(0,1104)\end{array}$ & $\begin{array}{l}-0,0982 \\
(0,1046)\end{array}$ & $\begin{array}{c}357,2454 \\
(0,3627)^{* * *}\end{array}$ \\
\hline Italy & $\begin{array}{c}0,1801 \\
(0,0898)^{* *}\end{array}$ & $\begin{array}{c}0,8653 \\
(0,0855)^{* * *}\end{array}$ & $\begin{array}{l}-0,0879 \\
(0,0843)\end{array}$ & $\begin{array}{c}0,6465 \\
(0,1888)^{* * *}\end{array}$ & $\begin{array}{c}-0,5025 \\
(0,1885)^{* * *}\end{array}$ & $\begin{array}{c}172,2853 \\
(0,2264)^{* * *}\end{array}$ \\
\hline Luxembourg & $\begin{array}{c}0,3626 \\
(0,2013) *\end{array}$ & $\begin{array}{c}1,0777 \\
(0,1104)^{* * *}\end{array}$ & $\begin{array}{c}-0,2953 \\
(0,1109)^{* * *}\end{array}$ & $\begin{array}{c}0,3930 \\
(0,1277)^{* * *}\end{array}$ & $\begin{array}{c}-0,3019 \\
(0,1244)^{* *}\end{array}$ & $\begin{array}{c}67,551 \\
(0,5206)^{* * *}\end{array}$ \\
\hline Netherlands & $\begin{array}{c}0,1532 \\
(0,0696)^{* *}\end{array}$ & $\begin{array}{c}1,0201 \\
(0,0875)^{* * *}\end{array}$ & $\begin{array}{l}-0,0466 \\
(0,0883)\end{array}$ & $\begin{array}{c}0,0043 \\
(0,1180)\end{array}$ & $\begin{array}{c}-0,0435 \\
(0,1159)\end{array}$ & $\begin{array}{c}418,6272 \\
(0,3151)^{* * *}\end{array}$ \\
\hline Portugal & $\begin{array}{c}0,1998 \\
(0,1159)^{*}\end{array}$ & $\begin{array}{c}1,0217 \\
(0,0850)^{* * *}\end{array}$ & $\begin{array}{l}-0,1214 \\
(0,0862)\end{array}$ & $\begin{array}{c}0,2573 \\
(0,1086)^{* *}\end{array}$ & $\begin{array}{c}-0,2329 \\
(0,1088)^{* *}\end{array}$ & $\begin{array}{c}180,0204 \\
(0,8848)^{* * *}\end{array}$ \\
\hline Spain & $\begin{array}{c}0,2358 \\
(0,0986)^{* *}\end{array}$ & $\begin{array}{c}1,3465 \\
(0,0836)^{* * *}\end{array}$ & $\begin{array}{c}-0,4965 \\
(0,0841)^{* * *}\end{array}$ & $\begin{array}{c}-0,0770 \\
(0,2103)\end{array}$ & $\begin{array}{c}0,1474 \\
(0,2041)\end{array}$ & $\begin{array}{c}263,5679 \\
(0,3043)^{* * *}\end{array}$ \\
\hline
\end{tabular}


Table 7

Granger Non-Causality Test of Anticipated Inflation

\begin{tabular}{|c|c|c|c|c|c|c|}
\hline Country & $\alpha$ & $\beta_{1}$ & $\beta_{2}$ & $V_{1}$ & $V_{2}$ & F-statistics \\
\hline EA 12 & $\begin{array}{c}0,0991 \\
(0,1019)\end{array}$ & $\begin{array}{c}1,0479 \\
(0,0896)^{* * *}\end{array}$ & $\begin{array}{c}-0,1319 \\
(0,0920)\end{array}$ & $\begin{array}{c}-0,0649 \\
(0,1185)\end{array}$ & $\begin{array}{c}0,1027 \\
(0,1187)\end{array}$ & $\begin{array}{c}161,3469 \\
(0,2074)^{* * *}\end{array}$ \\
\hline Austria & $\begin{array}{c}0,1138 \\
(0,0700)\end{array}$ & $\begin{array}{c}0,8510 \\
(0,0874)^{* * *}\end{array}$ & $\begin{array}{c}0,0747 \\
(0,0902)\end{array}$ & $\begin{array}{c}-0,0182 \\
(0,0955)\end{array}$ & $\begin{array}{c}0,0286 \\
(0,0909)\end{array}$ & $\begin{array}{c}207,4831 \\
(0,3059)^{* * *}\end{array}$ \\
\hline Belgium & $\begin{array}{c}0,1701 \\
(0,1039)\end{array}$ & $\begin{array}{c}0,8594 \\
(0,0846)^{* * *}\end{array}$ & $\begin{array}{c}0,0538 \\
(0,0869)\end{array}$ & $\begin{array}{c}-0,1566 \\
(0,0789)^{* *}\end{array}$ & $\begin{array}{c}0,1657 \\
(0,0784)^{* *}\end{array}$ & $\begin{array}{c}155,5388 \\
(0,4651)^{* * *}\end{array}$ \\
\hline Finland & $\begin{array}{c}0,1024 \\
(0,0624)\end{array}$ & $\begin{array}{c}0,8805 \\
(0,0845)^{* * *}\end{array}$ & $\begin{array}{c}0,0873 \\
(0,0873)\end{array}$ & $\begin{array}{c}-0,1336 \\
(0,0890)\end{array}$ & $\begin{array}{c}0,1206 \\
(0,0860)\end{array}$ & $\begin{array}{c}308,2745 \\
(0,3388)^{* * *}\end{array}$ \\
\hline France & $\begin{array}{c}0,1192 \\
(0,0765)\end{array}$ & $\begin{array}{c}1,1033 \\
(0,0900)^{* * *}\end{array}$ & $\begin{array}{c}-0,2055 \\
(0,0934)^{* *}\end{array}$ & $\begin{array}{l}-0,0146 \\
(0,0628)\end{array}$ & $\begin{array}{c}0,0479 \\
(0,0606)\end{array}$ & $\begin{array}{c}204,6814 \\
(0,3005)^{* * *}\end{array}$ \\
\hline Germany & $\begin{array}{c}0,1731 \\
(0,0940)^{* *}\end{array}$ & $\begin{array}{c}0,8754 \\
(0,0856)^{* * *}\end{array}$ & $\begin{array}{c}0,0293 \\
(0,0856)\end{array}$ & $\begin{array}{l}-0,1329 \\
(0,1072)\end{array}$ & $\begin{array}{c}0,1161 \\
(0,1071)\end{array}$ & $\begin{array}{c}150,4494 \\
(0,3233)^{* * *}\end{array}$ \\
\hline Greece & $\begin{array}{c}0,4125 \\
(0,1579)^{* * *}\end{array}$ & $\begin{array}{c}0,8729 \\
(0,0871)^{* * *}\end{array}$ & $\begin{array}{c}0,0157 \\
(0,0854)\end{array}$ & $\begin{array}{c}-0,0605 \\
(0,0692)\end{array}$ & $\begin{array}{c}0,0480 \\
(0,0681)\end{array}$ & $\begin{array}{c}160,8216 \\
(0,3848)^{* * *}\end{array}$ \\
\hline Ireland & $\begin{array}{c}0,0447 \\
(0,0918)\end{array}$ & $\begin{array}{c}1,0160 \\
(0,0857)^{* * *}\end{array}$ & $\begin{array}{l}-0,1207 \\
(0,0844)\end{array}$ & $\begin{array}{c}0,0190 \\
(0,0539)\end{array}$ & $\begin{array}{c}0,0726 \\
(0,0549)\end{array}$ & $\begin{array}{c}380,9428 \\
(0,3532)^{* * *}\end{array}$ \\
\hline Italy & $\begin{array}{c}0,2501 \\
(0,1165)^{* *}\end{array}$ & $\begin{array}{c}0,9901 \\
(0,0842)^{* * *}\end{array}$ & $\begin{array}{c}-0,1003 \\
(0,08466)\end{array}$ & $\begin{array}{c}0,0706 \\
(0,1168)\end{array}$ & $\begin{array}{l}-0,0669 \\
(0,1157)\end{array}$ & $\begin{array}{c}150,9698 \\
(0,2391)^{* * *}\end{array}$ \\
\hline Luxembourg & $\begin{array}{c}0,5705 \\
(0,3116)^{*}\end{array}$ & $\begin{array}{c}1,1260 \\
(0,1302)^{* * *}\end{array}$ & $\begin{array}{c}-0,3105 \\
(0,1378)^{* *}\end{array}$ & $\begin{array}{c}-0,0647 \\
(0,1162)\end{array}$ & $\begin{array}{c}0,0649 \\
(0,1120)\end{array}$ & $\begin{array}{c}43,1646 \\
(0,5774)^{* * *}\end{array}$ \\
\hline Netherlands & $\begin{array}{c}0,0656 \\
(0,0673)\end{array}$ & $\begin{array}{c}1,0320 \\
(0,0849)^{* * *}\end{array}$ & $\begin{array}{l}-0,0939 \\
(0,0845)\end{array}$ & $\begin{array}{c}0,1032 \\
(0,0867)\end{array}$ & $\begin{array}{l}-0,0689 \\
(0,0879)\end{array}$ & $\begin{array}{c}419,8747 \\
(0,3147)^{* * *}\end{array}$ \\
\hline Portugal & $\begin{array}{c}0,2456 \\
(0,1243)^{*}\end{array}$ & $\begin{array}{c}1,0572 \\
(0,0838)^{* * *}\end{array}$ & $\begin{array}{c}-0,1269 \\
(0,0867)\end{array}$ & $\begin{array}{c}-0,1883 \\
(0,0812)^{* *}\end{array}$ & $\begin{array}{c}0,1670 \\
(0,0786)^{* *}\end{array}$ & $\begin{array}{c}179,6621 \\
(0,3592)^{* * *}\end{array}$ \\
\hline Spain & $\begin{array}{c}0,2705 \\
(0,1073)^{* *}\end{array}$ & $\begin{array}{c}1,3543 \\
(0,0782)^{* * *}\end{array}$ & $\begin{array}{c}-0,4709 \\
(0,0806)^{* * *}\end{array}$ & $\begin{array}{c}0,1530 \\
(0,0901)^{*}\end{array}$ & $\begin{array}{c}-0,1286 \\
(0,0880)\end{array}$ & $\begin{array}{c}262,9679 \\
(0,3046)^{* * *}\end{array}$ \\
\hline
\end{tabular}

A significant gap (expectational errors) between anticipated inflation and HICP is obvious only in Germany, Luxembourg, the Netherlands, Spain and EA12 at a $10 \%$ significance level. The empirical analysis concludes that the rational expectation errors (gap between the anticipated and current inflation) is not significant in the most Eurozone Member States, excluding the aforementioned Germany, Luxembourg, the Netherlands and Spain. 
It is possible to assume that the expectational error $\left(P_{t}^{e}-P\right)$ disappeared because the economic agents are able to calculate all disposable information to form their rational expectations about the future price level. The same assumption is probable in context of inflation perceptions. However, the results of causality tests between the inflation perceptions/anticipations and current observed inflation are surprised.

Table 6 and 7 presents the results of Granger non-causality tests - the causality between the perceived/anticipated inflation and current observed inflation. The tests failed to reject the hypothesis $\gamma_{1}=\gamma_{2}=0$ and simultaneously reject the hypothesis $\beta_{1}=\beta_{2}=0$ in the most of countries.

Except of Italy ( $1 \%$ significance level), Luxembourg (1\% significance level) and Portugal (5\% significance level) perceived inflation has no impact on the current inflation. Inflation anticipations have no impact on the current observed inflation in the most analysed countries, except of Belgium (5\% significance level), Portugal (5\% significance level) and Spain (10\% significance level). According to these results, the hypothesis about the causality existence between the inflation anticipations/perceptions was rejected in Granger sense in the most Eurozone Member States.

\section{Discussion}

Heinemann and Ullrich (2006) based their analysis of the impact of EMU on inflation expectations on the representation of expectations formation suggested, among others, by Carlson and Valev (2002) and Gerberding (2001). These take in account the empirical fact that the expectations formation can only partially be characterized to be fully rational and that backward looking and adaptive expectations play a role at least for a subset of economic agents ${ }^{7}$. Furthermore, authors incorporate a term capturing the regressive part of expectations formation and the possibility that the expected inflation rate can change in reaction to a changing current inflation rate (Pesaran, 1985, p. 951). They also stress that expectations tend to underpredict the inflation rate during periods of rising inflation and overpredict this rate during periods of decreasing inflation. This finding is the frequent result of studies on inflation expectations (e.g. Andolfatto et al., 2002).

Traut-Mattausch et al. (2004) highlighted the importance of psychological factors, and especially the role of prior expectations. Based on an experiment, they show a bias towards a perception of price increases as a result of a previously held expectation, even when the latter was not confirmed by the evidence ${ }^{8}$. A completely different factor relates to the fact that consumers may have incorrectly interpreted the loss of purchasing power incurred at the time of the changeover as being caused by higher inflation rather than by the general slowdown in economic activity at that time. Del Giovane and Sabbatini (2006) have found some evidence in favour of this argument in the case of Italy, but in principle this argument should also have led to inflation misperceptions in other periods characterized by an economic downturn.

7 This argument supports the close relation between the evaluation of the past development of prices (an indicator of perceived inflation) and expected inflation (future price development).

This is exactly the case of perceived inflation and its significant deviation from HICP. 
Lindén, S. (2005) gives the following opinion on the role of expectations and perceptions on price level: "Expectations about the future course of the price level are important to decision-makers in all markets: for goods, labour, money, financial assets and currencies. Decisions on these markets determine the current rate of inflation, nominal wage rates, interest rates, exchange rates as well as real variables such as the rate of unemployment. Expectations actually determine all types of economic behaviour, as human action is forward-looking. Such information, however, is difficult to compile for the simple reason that inflationary expectations are not directly measurable in a way similar to variables such as interest rates, monetary aggregates, rates of unemployment, consumer and producer prices, etc. The expectations of the future behavior of prices are held by individuals in their minds. A straight forward way to measure the inflation expectations of the public is to ask people about their expectations, and in fact, a few surveys do exactly that. In November 2002, it was decided to introduce two new questions into the Harmonized Consumer Survey for the European Union, thus adding to the number of surveys that explicitly ask a selection of respondents (representing the public at large) about their inflation perceptions and expectations. The two new questions were introduced on a voluntary and experimental basis. They aimed at obtaining point estimates of the perception and expectation, using a quantitative formulation on past (perceived) and future (expected) inflation. "Lindén, S. (2005) continues: "One obvious problem with these surveys is that the questions asked concern variables that are difficult to assess, or even understand. Inflation, for example, is a macro-variable measuring the aggregate price level, but as respondents' consumption baskets do not necessarily correspond to the one used for calculating the consumer price indices, the answers obtained with the surveys can differ substantially from the official inflation rates. This is often the case; surveys do in general result in showing perceptions and expectations that are very different from the actual rates".

The unit root test is made for each member country of the Eurozone individually. Aucremann, Collin and Stragier (2007) in their empirical analysis use the panel unit root test because of low power of unit root tests in short samples since in such cases they tend not to reject the null hypothesis, even if the latter is not true. The authors of this paper assume that there is a different economy structure and transmission mechanism affecting the agent behaviour in each Eurozone Member State. The problem of an insufficient number of observations and unit root test robustness could be solved by individually estimated critical values based on the Monte Carlo simulation methodology, but the time series used cover 144 observations. Critical values used in this paper are sourced from Hamilton (1994) and depend on a sample size of 25, 50, 100,250 and 500 observations.

\section{Conclusions}

The rational expectation hypothesis and Lucas's critique of the negative slope Phillips curve is a very strong argument for economic policy recommendations. Of course, the authors distinguish the rational expectation hypothesis from the adaptive expectation hypothesis. While the rational expectation hypothesis is based on the forward-looking expectations, the adaptive expectation hypothesis is associated with backward-looking expectations. In the empirical analysis the authors use inflation perceptions as well 
as anticipations and test if the current price level is different from the perceived and anticipated prices. The results presented in Tables 2, 3, 4 and 5 show, that perceived or anticipated inflation differs mostly from its current level (HICP) but returns back in the long-run.

This conclusion leads to the idea of overrating the impact of inflation perceptions or anticipations on the economies. As the empirical results are not robust (lag order identified by Akaike's information criterion is too high), the authors used Granger non-causality test to identify causality between the inflation perceptions/anticipations and observed inflation.

The role of the perceived inflation, like the exogenous shock that leads to the expected future consumption reduction, was rejected because the gap between its observed and perceived/anticipated level is not significant. Subsequently, the causality existence between the perceived/anticipated and its observed values was rejected in Granger sense (Tables 6 and 7).

The reality is, of course, that some products and services may see individual one-time price increases due to prices being rounded up, or because of new price calculations or unforeseen events (such as crop failures or external price shocks). Growth in individual prices might also occur as a result of attempts by retailers to take advantage of the euro's introduction to enact otherwise unrealizable, purposeful, coordinated price hikes.

This type of movement in the structure of prices, however, has had a relatively minor influence on the HICP index. At the same time, the impact on the narrowed index of monetary expenditures cannot be compared to the growth in indicators of perceived inflation, as has taken place in all countries of the Eurozone with the exception of Slovakia.

In spite of that, as a consequence of individual price movements and the impact of other factors (media influence, continued calculation of prices in euros in the domestic currency thereby creating a comparison of current and past prices, the use of other nominal values in the new currency, inbuilt expectations, etc.) consumers have gotten the impression that introduction of the euro is associated with significant price hikes across the board. This feeling (perception) has persisted for a long time.

Even if growth in perceived inflation were to have no relevant impact on inflationary expectations and macroeconomic stability, it might still significantly reduce the level of support for introduction of the euro among the citizenry, cut consumer confidence and lower faith in the official statistics. That's why we consider it misplaced to hear the problem of perceived inflation as some species of insoluble, necessary evil whose economic costs will in any event be negligible. ${ }^{9}$ Economic policymakers should thus aim at minimizing the growth of perceived inflation at the least during the period of transition to the euro, while attempting the fastest possible realignment of its dynamics with those of the HICP index.

9 Hampl (2007) speaks about "the battle which cannot be won" in regard to perceived inflation. He also opines that the impact of perceived inflation should not be overestimated. He considers any growth in indicators of perceived inflation as simply one of the costs of entry into the Eurozone. 


\section{References}

Andolfatto, D., Scott, H., Moran, K. (2002), "Inflation Expectations and Learning about Monetary Policy." Bank of Canada Working Papers, 2002-30.

Aucremanne, L., Collin, M., Stragier, T. (2007), "Assessing the Gap between Observed and Perceived Inflation in the Euro Area: Is the Credibility of the HICP at Stake?" NBB Working Paper No. 112.

Brachinger, W. (2006), "Euro or „Teuro“? The Euro-induced Perceived Inflation in Germany.” Working Paper Series No. 5. Department of Quantitative Economics, University of Freiburg.

Burgoyne, C., Routh, D., Ellis, A. (1999), "The Transition to the Euro: Some Perspectives from Economic Psychology.” Journal of Consumer Policy, 22, pp. 91-116.

Carlson, J. A., Valev, N. (2002), "A Disinflation Tradeoff: Speed Versus Final Destination." Economic Inquiry, 40, pp. 450-456.

Del Giovane P., Sabbatini, T. (2006), "Perceived and Measured Inflation after the Launch of the Euro: Explaining the Gap in Italy." Paper presented at the 81st Annual Conference of the WEAI, San Diego.

Dimand R. W. (2002), "Patinkin on Irving Fisher's Monetary Economics." European Journal of the History of Economic Thought, 9 (2), pp. 308-326.

Döhring, B., Mordonu, A. (2007), "What Drives Inflation Perceptions? A Dynamic Panel Data Analysis." European Commission, Economic Paper No. 284.

ECB (2002a), Monthly Bulletin. Various issues.

ECB (2002b), Cash Changeover Report.

ECB (2007), Measured Inflation and Perceptions in the Euro Area. ECB Monthly Bulletin, July 2007, pp. 63-72.

Enders, W. (2003), Applied Econometric Time Series. $2^{\text {nd }}$ Ed. Wiley Publishing, pp. 185-195, ISBN: 0-471-45173-8;

Federal Statistical Office of Germany (2006), "Communication and Perception: which World do Statistics Live in?" United Nations Economic Commission for Europe work session on statistical dissemination and communication, September.

Friedman, M. (1968), "The Role of Monetary Policy." American Economic Review, 1968, 58 (1), pp. $1-17$.

Gamble, A., Gärling, R., Västfjäll, D., Marell, A. (2003), "Consumer Choice biased by Nominal Representation of Price." Presentation at the IAREP (International Association for Research in Economic Psychology) Euro-Workshop, Vienna, Austria, July.

Gerberding, Ch. (2001), "The Information Content of Survey Data on Expected Price Developments." Economic Research Centre of the Deutsche Bundesbank, Discussion Paper No. 9/2001.

Gerrit A. (2008), How is Perceived Inflation Related to Actual Price Changes in the European Union? Journal of Economic Psychology, 29 (4), pp. 417-432.

Greene, H. W. (2003), Econometric Analysis. Fifth edition. New Jersey: Pearson Education, 2003, pp. 590-592, ISBN: 0-13-066189-9.

Gylfason, T. (1980), "Interest Rates, Inflation and the Aggregate Consumption Function." The Review of Economics and Statistics, 63 (2), pp. 233-245.

Hamilton, J. D. (1994): Time Series Analysis. Princeton University Press.

Hampl, M. (2007), "Dopady předčasného přijetí eura na ceny.“ Časopis Euro, 10. 9. 2007, p. 94.

Heijdra, B., J. Ploeg F. (2002), Foundations of Modern Macroeconomics. Oxford University Press.

Heinemann, F., Ullrich, K. (2006), "The Impact of EMU on Inflation Expectations." Open Economies Review, 17, pp. 175-195. 
Jonas, E., Greirtemerier, T., Frey, D., Schultz-Hardt, S. (2002), "Psychological Effects of the Euro-Experimental Research on the Perception of Salaries and Price Estimations." European Journal of Social Psychology, Vol. 32, pp. 147-169.

Kemp, S., Willetts, K. (1996), "Remembering the Price of Wool." Journal of Economic Psychology, 17 (1), pp. 115-125.

Kichler, E. (2006), "Comment on 'Perceived Inflation and the Euro: Why High? Why Persistent?" Proceedings of OeNB Workshops, No. 8.

Lacina, L. (2008), "Increase of Perceived Inflation during the Process Euro Introduction: Reality or Idle Fear?" In textbook of proceedings from international conference "Firm and Competitive Environment 2008“, Section 1: Czech economy in integration process. MZLU, Brno, pp. 69-78.

Lindén, S. (2005), "Quantified Perceived and Expected Inflation in the Euro Area - How Incentives Improve Consumers Inflation forecasts." Paper presented at the OECD Workshop on International Development of Business and Consumer Tendency Surveys, Brussel.

Muth, J. F. (1961), "Rational Expectations and the Theory of Price Movements." Econometrica, 29, pp. 315-335.

Pesaran, M. H. (1985), "Formation of Inflation Expectations in British Manufacturing Industries." Economic Journal, 95, pp. 948-975.

Phillips, A. W. (1958), "The Relationship between Unemployment and the Rate of Change of Money Wages in the United Kingdom 1861-1957." Economica, 25 (100), pp. 283-299.

Seddighi, H. R., Lawler, K. A., Katos, A. V. (2000), Econometrics. A Practical Approach. London: Routledge, pp.262-272.

Shafir, E., Diamond, P., Tversky, A. (1997), "Money Illusion." The Quarterly Journal of Economics, Vol. 112, pp. 341-374.

Sturm J., Fritsche, U., Graff, M., Lamla, M., Lein, S., Nitsch, V., Liechte, D., and Triet, D. (2009), "The Euro and Prices: Changeover-Related Inflation and Price Convergence in the Euro Area." European Economy - Economic Papers, No. 381, June. Brussels.

Traut-Mattausch, E., Schulz-Hardt, S., Greitemeyer, T., Frey, D. (2004), "Expectancy Confirmation in spite of Disconfirming Evidence: The Case of Price Increases due to the Introduction of the Euro." European Journal of Social Psychology, 34 (6), pp. 739-760. 